\title{
Effects of the culture media optimization on pectinase production by Enterobacter sp. PSTB-1
}

\author{
M. Purna chandra $\operatorname{Reddy}^{1} \cdot$ K. V. Saritha ${ }^{1,2}$
}

Received: 28 November 2015 / Accepted: 18 August 2016/Published online: 26 September 2016

(c) The Author(s) 2016. This article is published with open access at Springerlink.com

\begin{abstract}
In the present study, media composition for high production of pectinase by Enterobacter sp. PSTB-1 in submerged fermentation was optimized using response surface methodology (RSM). Mango fruit processing industrial waste (MIW) was used as substrate (carbon source) as it contains high amount of pectin. Enterobacter sp. PSTB-1 used in present study has given pectin clear zone (PCZ) of $34 \mathrm{~mm}$ is higher than other isolates. The experimental results made by statistical design for high pectinase production revealed that the suitable media components: $\mathrm{NaNO}_{3} 2.0 \mathrm{~g} / \mathrm{l}, \mathrm{KCl} 0.50 \mathrm{~g} / \mathrm{l}, \mathrm{KH}_{2} \mathrm{PO}_{4} 1.0 \mathrm{~g} / \mathrm{l}$, $\mathrm{MgSO}_{4} \cdot 7 \mathrm{H}_{2} \mathrm{O} \quad 0.50 \mathrm{~g} / \mathrm{l}$, Yeast extract $1.0 \mathrm{~g} / \mathrm{l}$, mango industrial waste powder $5.0 \mathrm{~g} / \mathrm{l}$. The actual pectinase activity was $75.23 \%$ correlated with the predicted pectinase activity where the model (CCD) was significant. Response surface modelling applied effectively to optimize the production of pectinase in submerged fermentation to make the process low cost-effective by using powdered mango industrial waste as substrate.
\end{abstract}

Keywords Mango fruit processing industrial waste (MIW) powder - Pectinase - Submerged fermentation .

Enterobacter sp. PSTB-1 - Response Surface Methodology $(\mathrm{RSM}) \cdot$ Central composite design (CCD) model

K. V. Saritha

kvsarithasvu@gmail.com

1 Department of Biotechnology, Sri Venkateswara University, Tirupati 517 502, India

2 Department of Future Studies, SVU College of Sciences, Sri Venkateswara University, Tirupati 517 502, A.P., India

\section{Introduction}

Mango is the most delicious fruit with its health benefits and commercially valuable seasonal fruit. So, there must be a need to process this fruit to make available its products in all seasons (Indian Horticulture Database 2011; Purnachandra Reddy and Saritha 2013). Many mango fruit processing industries were established throughout the world and were generating huge amounts of waste or residues while processing the mango fruits. It has been reported that 28 to $43 \%$ of the total of mangoes remain as residues mainly constituted by peel and seeds are discarded during the process (Guzman et al. 2013). The mango industrial waste can be used in so many ways such as animal feed, fuel wood (dried seeds) and it can also be useful for vermicompost preparation and biogas production. Mango industrial waste is the best source for the production of industrially important pectinase, as it contains high amounts of pectin in ripened mango (Yashoda et al. 2005). Pectin is a jelly like matrix structural polysaccharide found in the primary cell wall and the middle lamella of fruits and vegetables (Namasivayam et al. 2011). Along with pectin other polysaccharides such as cellulose and xylan type polysaccharides strengthens the structure of cell-walls in the flesh of fruits (Beatriz and Fabrice 2012). Pectinase is mainly useful for increasing the filtration efficiency and clarification of fruit juices, most of these are microbial derived. Most of the Bacterial isolates such as Bacillus sp and Pseudomonas.sp., Bacillus sp. MFW7, Bacillus cereus, Bacillus licheniformis, Bacillus cereus, and Staphylococcus aureus were reported as good pectinase producers (Geetha et al. 2012; Mukesh kumar et al. 2012; Venkata Naga Raju et al. 2013). In the present study dried mango fruit processing industrial waste (MIW powder; one of the polluting solid wastes) has been utilized 
for the production of pectinase through submerged fermentation by using pectinolytic Enterobacter sp. PSTB-1 under RSM conditions.

\section{Materials and methods}

\section{Sample collection}

Fresh, dried and decomposed mango industrial waste samples were collected in sterile polythene covers from different mango fruit processing industries around Chittoor, A.P., India. The collected samples were stored at $4{ }^{\circ} \mathrm{C}$ for future purposes.

\section{Isolation and identification of bacterial strains}

The bacterial strains were isolated by serial dilution of $1.0 \mathrm{~g}$ of mango industrial waste (mixture of fresh, dried and decomposed) (Aneja 2003). Pure cultures of isolated strains were maintained at $4{ }^{\circ} \mathrm{C}$ on nutrient agar medium. These strains were identified by Gram's staining, biochemical testing (Srivastava 2003).

\section{Screening for pectinolytic bacterial strains}

\section{Pectinase production medium}

This medium was prepared according to Reda Bayoumi et al. (2008), consists of part (A) and part (B). Part (A) contained (g/l): $\mathrm{NaNO}_{3} 2.0, \mathrm{KH}_{2} \mathrm{PO}_{4} 1.0, \mathrm{KCl} 0.5$, $\mathrm{MgSO}_{4} \cdot 7 \mathrm{H}_{2} \mathrm{O} 0.5$, Yeast extract 1.0. These contents were dissolved in $40 \mathrm{ml}$ distilled water and $\mathrm{pH}$ adjusted to 7.0 by $5 \% \mathrm{NaOH}(\mathrm{w} / \mathrm{v})$. Part (B) contained (g/l): MIW powder 5.0, dissolved in $10 \mathrm{ml}$ of distilled water. The two parts (A) and (B) were mixed and sterilized. This medium was inoculated with isolated bacterial strains and incubated at $37^{\circ} \mathrm{C}$ for 96 hours, then assayed for pectinase activity.

\section{Assay medium}

The medium composition was (g/l): Peptone 0.5, Beef extracts $0.3, \mathrm{NaCl} 0.5$, Agar 15, Pectin 4.0, these contents dissolved in distilled water ( $\mathrm{pH} 7.0)$.

\section{Pectinase activity assay}

Plates of the same size were poured with equal amounts of sterilized assay medium. After cooling, three wells were made in each plate with sterilized cork borer. Each well was inoculated with $0.1 \mathrm{ml}$ of culture filtrate of (pectinolytic enzyme) production medium. These plates were incubated at $37{ }^{\circ} \mathrm{C}$ for two to four days. Then the plates were flooded with hexadecyl trimethyl ammonium bromide (HTAB) solution, clearing zones of the medium was investigated and taken as the criteria for determining the pectinase productivity.

\section{Species identification of PSTB-1 strain}

The species identification of highest pectinase producing PSTB-1 was done by sequencing the $16 \mathrm{~S}$ r-RNA gene using a suitable primer set; B27 (F); 5'-AGA GTT TGA TCM TGG CTC AG-3' 1492 (R); 5'-GGT TAC CTT GTT ACG ACT $\mathrm{T}-3^{\prime}$ by following Alexander Probst et al. (Alexander et al. 2010).

PCR

A $14 \mu \mathrm{l} \mathrm{PCR} \mathrm{master} \mathrm{mix} \mathrm{contains}(\mu \mathrm{l})$; 10X PCR buffer 1.25, $\mathrm{MgCl}_{2}$ 0.4, dNTPs 1.0, F-primer 1.0, R-primer 1.0, trehalose 8.25 , taq 0.1 and $1.0 \mu$ of template DNA. The PCR was carried out in three steps by 37 cycles. First step is de-naturation ( 1 cycle) at $94{ }^{\circ} \mathrm{C}$ for 3 minutes, second step is annealing ( 35 cycles) at $50{ }^{\circ} \mathrm{C}$ for 33 minutes and the third step is re-naturation ( 1 cycle) at $72{ }^{\circ} \mathrm{C}$ for 10 minutes.

\section{Optimization of media composition}

\section{Experimental bergy}

Central composite design (Design-Expert 9.0.1 2013) model of RSM for six factors with three replicates has been used in the investigation. The variables used were $\mathrm{NaNO}_{3}$ $\left(\mathrm{X}_{1}\right), \mathrm{KH}_{2} \mathrm{PO}_{4}\left(\mathrm{X}_{2}\right), \mathrm{KCl}\left(\mathrm{X}_{3}\right), \mathrm{MgSO}_{4} \cdot 7 \mathrm{H}_{2} \mathrm{O}\left(\mathrm{X}_{4}\right)$, yeast extract $\left(\mathrm{X}_{5}\right)$ and MIW powder $\left(\mathrm{X}_{6}\right)$ each at low $(-1)$ and high $(+1)$ of coded levels.

\section{Preparation of substrate}

The collected fresh mango industrial waste was washed and chopped into small pieces and oven dried at $55{ }^{\circ} \mathrm{C}$ for 72 hours. The dried waste was ground and sieved through $2.0 \mathrm{~mm}$ mesh size and dissolved in water (1:5) and left for overnight (Veeranjaneya Reddy et al. 2011). The liquid containing substrate was extracted with the help of cheese cloth by squeezing. This was used as a carbon source for pectinase production.

\section{Preparation of inoculum}

The inoculum was prepared by using overnight incubated nutrient broth culture of Enterobacter sp. PSTB-1. 


\section{Pectinase production medium}

Mango peel basal medium (MPBM) was used as production medium. The media contents were dissolved in citrate phosphate buffer at pH 6.0 according to design model and sterilised. Then the medium was inoculated with Enterobacter sp. PSTB-1 and incubated at $37^{\circ} \mathrm{C}$ for 48 hours. The culture filtrate of this medium will be used as enzyme source.

\section{Pectinase assay}

Pectinase activity assay was done by 3,5-dinitrosalicylic acid (DNS) method (Miller 1959). $0.5 \mathrm{ml}$ of the culture filtrate was used as crude enzyme source; $0.5 \mathrm{ml}$ of $1 \%$ pectin was used as substrate. One unit of the enzyme is equal to $1 \mathrm{U}$ of reducing sugars released, measured in terms of D-Galacturonic acid, produced as a result of enzyme reaction.

\section{Statistical analysis}

Experimental data was analysed by analysis of variance (ANOVA) according to response surface regression procedure to fit the following second order polynomial Eq. (1) was used to describe the effect of variables in terms of linear $\left(\mathrm{A}_{1}-\mathrm{A}_{6}\right)$, cross product terms $\left(\mathrm{A}_{7}-\mathrm{A}_{21}\right)$ and exponents $\left(\mathrm{A}_{22}-\mathrm{A}_{27}\right)$ using Central Composite Design model.

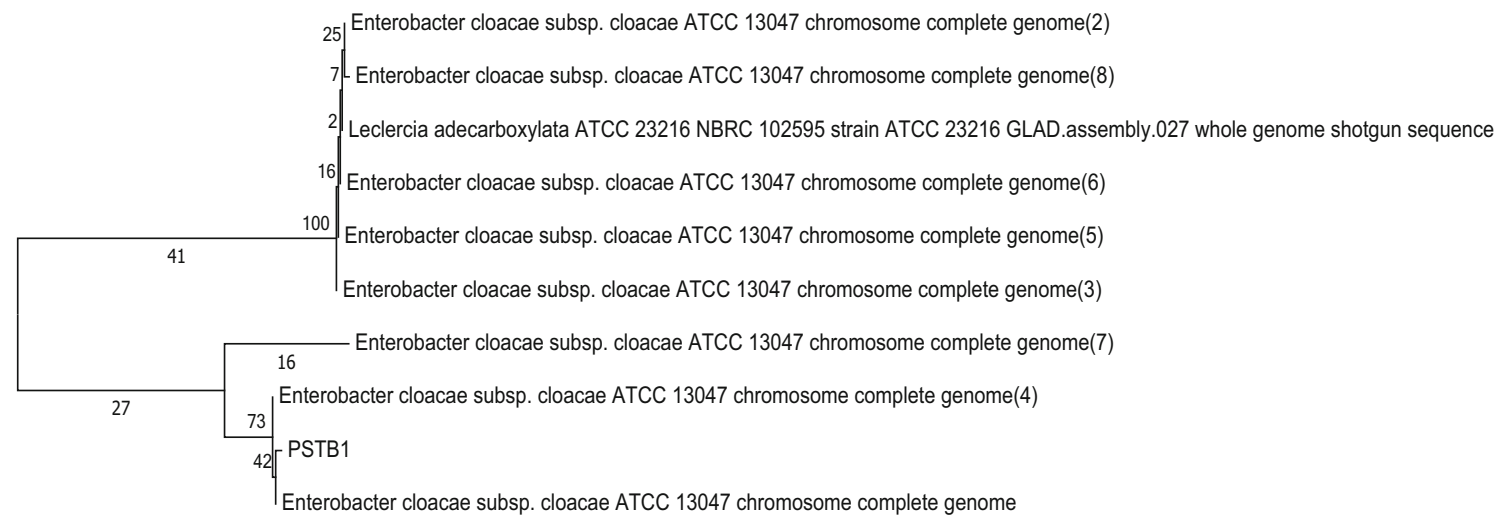

10

Fig. 1 Phylogenetic analysis based on 16S r-RNA sequence available from bacterial isolates was constructed. Evolutionary distances were computed using the p-distance method clustering with the neighbour-joining method

Table 1 Actual and coded values of the media components in design

\begin{tabular}{|c|c|c|c|c|c|c|c|c|}
\hline Factor & Name & Units & Low level & High level & Low coded & High coded & Mean & Std. dev \\
\hline A & $\mathrm{NaNO}_{3}$ & $\mathrm{~g} / \mathrm{l}$ & 1.22 & 2.78 & -1 & 1 & 2.00 & 0.43 \\
\hline B & $\mathrm{KH}_{2} \mathrm{PO}_{4}$ & $\mathrm{~g} / \mathrm{l}$ & 0.61 & 1.39 & -1 & 1 & 1.00 & 0.21 \\
\hline $\mathrm{C}$ & $\mathrm{KCl}$ & $\mathrm{g} / 1$ & 0.34 & 0.66 & -1 & 1 & 0.50 & 0.09 \\
\hline $\mathrm{D}$ & $\mathrm{MgSO}_{4} \cdot 7 \mathrm{H}_{2} \mathrm{O}$ & $\mathrm{g} / 1$ & 0.34 & 0.66 & -1 & 1 & 0.50 & 0.09 \\
\hline E & Yeast extract & $\mathrm{g} / \mathrm{l}$ & 0.61 & 1.39 & -1 & 1 & 1.00 & 0.21 \\
\hline $\mathrm{F}$ & MIW powder & $\mathrm{g} / 1$ & 4.43 & 7.57 & -1 & 1 & 6.00 & 0.85 \\
\hline Response & Name & & Obs. & Analysis & Min. & Max. & Mean & Std. dev \\
\hline $\mathrm{R}_{1}$ & Pectinase & ty $(\mathrm{U} / \mathrm{m}$ & 96 & Polynomia & 10.385 & 87.556 & 25.073 & 10.6414 \\
\hline
\end{tabular}

Std. Dev standard deviation, Obs observations, Min minimum, Max maximum; A, B, C, D, and E represents the process parameters denoted as $\mathrm{X}_{1}$, $\mathrm{X}_{2}, \mathrm{X}_{3}, \mathrm{X}_{4}, \mathrm{X}_{5}$, and $\mathrm{X}_{6}$, respectively for regression equation 
Table 2 Experimental design with actual experimental and predicted value of responses of the central composite design

\begin{tabular}{|c|c|c|c|c|c|c|c|c|}
\hline S. no & A & $\mathrm{B}$ & $\mathrm{C}$ & $\mathrm{D}$ & $\mathrm{E}$ & $\mathrm{F}$ & Actual pectinase $\mathrm{U} / \mathrm{ml}$ & Predicted pectinase $\mathrm{U} / \mathrm{ml}$ \\
\hline 1 & 0 & 0 & 0 & 0 & 0 & 0 & 22.29 & 27.70 \\
\hline 2 & -1 & -1 & -1 & 1 & 1 & 1 & 20.01 & 16.53 \\
\hline 3 & 1 & 1 & -1 & -1 & 1 & 1 & 22.29 & 22.24 \\
\hline 4 & -1 & 1 & 1 & -1 & -1 & 1 & 17.14 & 22.69 \\
\hline 5 & 1 & -1 & 1 & -1 & 1 & -1 & 20.52 & 24.43 \\
\hline 6 & 0 & 0 & 0 & 0 & 0 & 0 & 21.28 & 27.70 \\
\hline 7 & -1 & -1 & -1 & -1 & -1 & -1 & 21.70 & 26.39 \\
\hline 8 & -1 & 1 & 1 & 1 & 1 & -1 & 87.56 & 51.68 \\
\hline 9 & 1 & -1 & 1 & 1 & -1 & 1 & 22.29 & 32.79 \\
\hline 10 & 1 & 1 & -1 & 1 & -1 & -1 & 21.95 & 24.87 \\
\hline 11 & 1 & -1 & -1 & -1 & 1 & -1 & 14.10 & 15.75 \\
\hline 12 & 0 & 0 & 0 & 0 & 0 & 0 & 27.02 & 22.54 \\
\hline 13 & -1 & -1 & 1 & 1 & 1 & 1 & 33.69 & 28.67 \\
\hline 14 & 1 & 1 & 1 & 1 & -1 & -1 & 20.35 & 23.30 \\
\hline 15 & 1 & -1 & -1 & 1 & -1 & 1 & 20.26 & 24.04 \\
\hline 16 & -1 & -1 & 1 & -1 & -1 & -1 & 13.59 & 11.05 \\
\hline 17 & 1 & 1 & 1 & -1 & 1 & 1 & 26.51 & 20.61 \\
\hline 18 & 0 & 0 & 0 & 0 & 0 & 0 & 20.18 & 22.54 \\
\hline 19 & -1 & 1 & -1 & 1 & 1 & -1 & 24.40 & 29.22 \\
\hline 20 & -1 & 1 & -1 & -1 & -1 & 1 & 25.33 & 27.71 \\
\hline 21 & 1 & 1 & -1 & -1 & -1 & 1 & 33.60 & 28.26 \\
\hline 22 & 0 & 0 & 0 & 0 & 0 & 0 & 28.20 & 28.91 \\
\hline 23 & 0 & 0 & 0 & 0 & 0 & 0 & 26.01 & 28.91 \\
\hline 24 & -1 & 1 & 1 & 1 & -1 & -1 & 55.98 & 43.99 \\
\hline 25 & 1 & -1 & 1 & 1 & 1 & 1 & 50.74 & 42.88 \\
\hline 26 & 1 & -1 & 1 & -1 & -1 & -1 & 15.11 & 16.75 \\
\hline 27 & 1 & 1 & -1 & 1 & 1 & -1 & 17.56 & 21.26 \\
\hline 28 & -1 & -1 & -1 & -1 & 1 & -1 & 17.48 & 22.78 \\
\hline 29 & -1 & -1 & -1 & 1 & -1 & 1 & 24.15 & 22.56 \\
\hline 30 & -1 & 1 & 1 & -1 & 1 & 1 & 20.26 & 32.79 \\
\hline 31 & 0 & 0 & 0 & 0 & 0 & 0 & 18.15 & 22.43 \\
\hline 32 & -1 & -1 & 1 & -1 & 1 & -1 & 19.59 & 19.82 \\
\hline 33 & -1 & 1 & -1 & -1 & 1 & 1 & 19.42 & 22.78 \\
\hline 34 & 1 & -1 & -1 & 1 & 1 & 1 & 22.63 & 19.10 \\
\hline 35 & -1 & 1 & -1 & 1 & -1 & -1 & 15.87 & 33.92 \\
\hline 36 & 1 & 1 & 1 & 1 & 1 & -1 & 14.78 & 32.07 \\
\hline 37 & -1 & -1 & 1 & 1 & -1 & 1 & 19.93 & 19.66 \\
\hline 38 & 0 & 0 & 0 & 0 & 0 & 0 & 25.08 & 22.43 \\
\hline 39 & 1 & 1 & 1 & -1 & -1 & 1 & 18.58 & 11.60 \\
\hline 40 & 1 & -1 & -1 & -1 & -1 & -1 & 50.24 & 20.45 \\
\hline 41 & 0 & 0 & 0 & 0 & 0 & 0 & 23.81 & 24.28 \\
\hline 42 & 1 & -1 & 1 & -1 & 1 & 1 & 27.19 & 28.85 \\
\hline 43 & -1 & -1 & -1 & -1 & -1 & 1 & 19.00 & 22.29 \\
\hline 44 & -1 & 1 & 1 & -1 & -1 & -1 & 26.93 & 29.96 \\
\hline 45 & 1 & 1 & -1 & 1 & -1 & 1 & 26.43 & 19.27 \\
\hline 46 & -1 & 1 & 1 & 1 & 1 & 1 & 41.63 & 37.56 \\
\hline 47 & 1 & 1 & -1 & -1 & 1 & -1 & 17.39 & 21.00 \\
\hline 48 & -1 & -1 & -1 & 1 & 1 & -1 & 21.36 & 13.78 \\
\hline
\end{tabular}


Table 2 continued

\begin{tabular}{|c|c|c|c|c|c|c|c|c|}
\hline S. no & A & B & $\mathrm{C}$ & $\mathrm{D}$ & $\mathrm{E}$ & $\mathrm{F}$ & Actual pectinase $\mathrm{U} / \mathrm{ml}$ & Predicted pectinase $\mathrm{U} / \mathrm{ml}$ \\
\hline 49 & 0 & 0 & 0 & 0 & 0 & 0 & 22.21 & 24.28 \\
\hline 50 & 1 & -1 & 1 & 1 & -1 & -1 & 16.89 & 21.53 \\
\hline 51 & 1 & -1 & -1 & 1 & -1 & -1 & 21.78 & 16.68 \\
\hline 52 & 1 & -1 & -1 & -1 & 1 & 1 & 24.82 & 24.07 \\
\hline 53 & -1 & 1 & -1 & 1 & 1 & 1 & 20.01 & 19.01 \\
\hline 54 & -1 & 1 & -1 & -1 & -1 & -1 & 48.63 & 38.88 \\
\hline 55 & 1 & 1 & 1 & 1 & -1 & 1 & 18.91 & 21.60 \\
\hline 56 & 0 & 0 & 0 & 0 & 0 & 0 & 24.40 & 23.02 \\
\hline 57 & 1 & 1 & 1 & -1 & 1 & -1 & 21.11 & 23.27 \\
\hline 58 & -1 & -1 & 1 & 1 & 1 & -1 & 12.33 & 29.82 \\
\hline 59 & -1 & -1 & 1 & -1 & -1 & 1 & 19.25 & 10.86 \\
\hline 60 & 0 & 0 & 0 & 0 & 0 & 0 & 19.00 & 23.02 \\
\hline 61 & -1 & -1 & -1 & 1 & -1 & -1 & 14.18 & 19.58 \\
\hline 62 & 1 & -1 & 1 & -1 & -1 & 1 & 14.02 & 20.95 \\
\hline 63 & 0 & 0 & 0 & 0 & 0 & 0 & 30.65 & 25.26 \\
\hline 64 & 1 & 1 & -1 & -1 & -1 & -1 & 22.21 & 26.80 \\
\hline 65 & -1 & 1 & 1 & -1 & 1 & -1 & 39.85 & 39.83 \\
\hline 66 & -1 & -1 & -1 & -1 & 1 & 1 & 23.05 & 18.46 \\
\hline 67 & 0 & 0 & 0 & 0 & 0 & 0 & 24.74 & 25.26 \\
\hline 68 & -1 & 1 & 1 & 1 & -1 & 1 & 22.21 & 29.65 \\
\hline 69 & 1 & 1 & -1 & 1 & 1 & 1 & 24.23 & 15.44 \\
\hline 70 & 1 & -1 & 1 & 1 & 1 & -1 & 37.49 & 31.40 \\
\hline 71 & -1 & 1 & -1 & -1 & 1 & -1 & 29.47 & 36.15 \\
\hline 72 & -1 & -1 & 1 & -1 & 1 & 1 & 23.56 & 21.82 \\
\hline 73 & 0 & 0 & 0 & 0 & 0 & 0 & 33.69 & 25.10 \\
\hline 74 & 0 & 0 & 0 & 0 & 0 & 0 & 48.38 & 25.10 \\
\hline 75 & 1 & -1 & -1 & 1 & 1 & -1 & 10.39 & 13.94 \\
\hline 76 & 1 & -1 & -1 & -1 & -1 & 1 & 12.50 & 30.96 \\
\hline 77 & 1 & 1 & 1 & 1 & 1 & 1 & 21.36 & 32.57 \\
\hline 78 & -1 & 1 & -1 & 1 & -1 & 1 & 22.37 & 25.90 \\
\hline 79 & -1 & -1 & 1 & 1 & -1 & -1 & 21.53 & 23.01 \\
\hline 80 & 1 & 1 & 1 & -1 & -1 & -1 & 27.78 & 16.46 \\
\hline 81 & -1.565 & 0 & 0 & 0 & 0 & 0 & 22.80 & 28.44 \\
\hline 82 & 0 & 0 & 0 & 0 & 0 & 0 & 26.43 & 25.91 \\
\hline 83 & 1.565 & 0 & 0 & 0 & 0 & 0 & 18.91 & 23.38 \\
\hline 84 & 0 & 0 & 0 & 0 & -1.565 & 0 & 27.27 & 24.32 \\
\hline 85 & 0 & 0 & 0 & 0 & 1.565 & 0 & 23.47 & 27.50 \\
\hline 86 & 0 & -1.565 & 0 & 0 & 0 & 0 & 18.07 & 21.74 \\
\hline 87 & 0 & 0 & 0 & 0 & 0 & 0 & 26.68 & 25.91 \\
\hline 88 & 0 & 0 & 0 & 0 & 0 & 0 & 28.20 & 25.91 \\
\hline 89 & 0 & 0 & -1.565 & 0 & 0 & 0 & 26.34 & 23.13 \\
\hline 90 & 0 & 0 & 0 & 1.565 & 0 & 0 & 34.36 & 27.88 \\
\hline 91 & 0 & 0 & 0 & 0 & 0 & -1.565 & 21.70 & 27.03 \\
\hline 92 & 0 & 0 & 0 & 0 & 0 & 1.565 & 30.40 & 24.79 \\
\hline 93 & 0 & 0 & 0 & 0 & 0 & 0 & 27.27 & 25.91 \\
\hline 94 & 0 & 0 & 0 & -1.565 & 0 & 0 & 25.58 & 23.94 \\
\hline 95 & 0 & 0 & 1.565 & 0 & 0 & 0 & 28.12 & 28.69 \\
\hline 96 & 0 & 1.565 & 0 & 0 & 0 & 0 & 28.96 & 30.09 \\
\hline
\end{tabular}


Table 3 Analysis of variance table (partial sum of squares-type III)

\begin{tabular}{|c|c|c|c|c|c|}
\hline Source & Sum of squares & $d f$ & Mean square & $F$ value & $p$ value Prob $>\mathrm{F}$ \\
\hline Block & 410.20 & 8 & 51.28 & & \\
\hline Model & 4052.25 & 11 & 368.39 & 4.45 & $<0.0001$ significan \\
\hline $\mathrm{A}-\mathrm{NaNO}_{3}$ & 180.55 & 1 & 180.55 & 2.18 & 0.1440 \\
\hline $\mathrm{B}-\mathrm{KH}_{2} \mathrm{PO}_{4}$ & 490.32 & 1 & 490.32 & 5.92 & 0.0173 \\
\hline $\mathrm{C}-\mathrm{KCl}$ & 218.10 & 1 & 218.10 & 2.63 & 0.1088 \\
\hline $\mathrm{D}-\mathrm{MgSO}_{4} \cdot 7 \mathrm{H}_{2} \mathrm{O}$ & 109.29 & 1 & 109.29 & 1.32 & 0.2543 \\
\hline E-Yeast extract & 71.38 & 1 & 71.38 & 0.86 & 0.3562 \\
\hline F-MIW powder & 35.02 & 1 & 35.02 & 0.42 & 0.5175 \\
\hline $\mathrm{AB}$ & 746.63 & 1 & 746.63 & 9.01 & 0.0036 \\
\hline $\mathrm{AF}$ & 289.81 & 1 & 289.81 & 3.50 & 0.0653 \\
\hline $\mathrm{BF}$ & 401.69 & 1 & 401.69 & 4.85 & 0.0307 \\
\hline $\mathrm{CD}$ & 758.21 & 1 & 758.21 & 9.15 & 0.0034 \\
\hline $\mathrm{CE}$ & 751.25 & 1 & 751.25 & 9.07 & 0.0035 \\
\hline Residual & 6295.24 & 76 & 82.83 & & \\
\hline Lack of fit & 6101.84 & 65 & 93.87 & 5.34 & 0.0022 significant \\
\hline Pure error & 193.41 & 11 & 17.58 & & \\
\hline Cor total & 10757.6 & 95 & & & \\
\hline
\end{tabular}

$$
\begin{aligned}
Y= & A_{0}+A_{1} X_{1}+A_{2} X_{2}+A_{3} X_{3}+A_{4} X_{4}+A_{5} X_{5}+A_{6} X_{6} \\
& +A_{7} X_{1} X_{2}+A_{8} X_{1} X_{3}+A_{9} X_{1} X_{4}+A_{10} X_{1} X_{5} \\
& +A_{11} X_{1} X_{6}+A_{12} X_{2} X_{3}+A_{13} X_{2} X_{4}+A_{14} X_{2} X_{5} \\
& +A_{15} X_{2} X_{6}+A_{16} X_{3} X_{4}+A_{17} X_{3} X_{5}+A_{18} X_{3} X_{6} \\
& +A_{19} X_{4} X_{5}+A_{20} X_{4} X_{6}+A_{21} X_{5} X_{6}+A_{22} X_{1}^{2} \\
& +A_{23} X_{2}^{2}+A_{24} X_{3}^{2}+A_{25} X_{4}^{2}+A_{26} X_{5}^{2}+A_{27} X_{6}^{2} .
\end{aligned}
$$

where ' $Y$ ' is the predicted response (Pectinase yield $\mathrm{U} / \mathrm{ml}$ ) and $\mathrm{X}_{1}, \mathrm{X}_{2}, \mathrm{X}_{3}, \mathrm{X}_{4}, \mathrm{X}_{5}$, and $\mathrm{X}_{6}$ are the coded values of ingredients $\mathrm{NaNO}_{3}, \mathrm{KH}_{2} \mathrm{PO}_{4}, \mathrm{KCl}, \mathrm{MgSO}_{4} \cdot 7 \mathrm{H}_{2} \mathrm{O}$, yeast extract and MIW powder of culture medium, respectively.

\section{Results and discussion}

\section{Sample collection}

There are about 13 mango industries in Chittoor district, A.P., India producing high amount of waste which had been leading to environmental pollution. Thirty samples were collected from ten different mango fruit processing industries around Chittoor. Similarly, the wastes such as orange peel, citrus peel, potato peel, corn tegument, wheat bran and banana peels reported as a source for pectinolytic microorganisms (Geetha et al. 2012).

\section{Isolation and identification of bacterial strains}

Microorganisms are said to be the major bio-transforming agents for their ability to degrade waste. So, the bacterial strains used in the present study were isolated from collected mango industrial waste as they already existed in that particular environment and having the capacity to degrade it. Colony-forming units of bacteria in the different habitats were significantly different. Eight bacterial strains belonging to genus Bacillus and Cocci were identified based on their Gram's staining and biochemical characterization. They were given by isolate names such as PSTB-1, PSTB-2, PSTB-3, PSTB-4, PSTB-5, PSTB-6, PSTB-7, and PSTB-8.

\section{Screening for pectinolytic bacteria}

All the isolates (PSTB-1 to PSTB-8) were considered as good pectinase producers with their PCZ value of 34,26 , $22,15,18,16,18$, and $18 \mathrm{~mm}$. Only one strain that is PSTB-1 has been selected for high pectinase production due to its high PCZ value of $34 \mathrm{~mm}$. The PCZ value of Enterobacter sp. PSTB1 was similar with that of three bacterial isolates (numbers 4071, 107 and 10104) PCZ value of 32, 34 and $34 \mathrm{~mm}$, respectively by using Solanum tuberosum peels as substrate (Reda Bayoumi et al. 2008). 

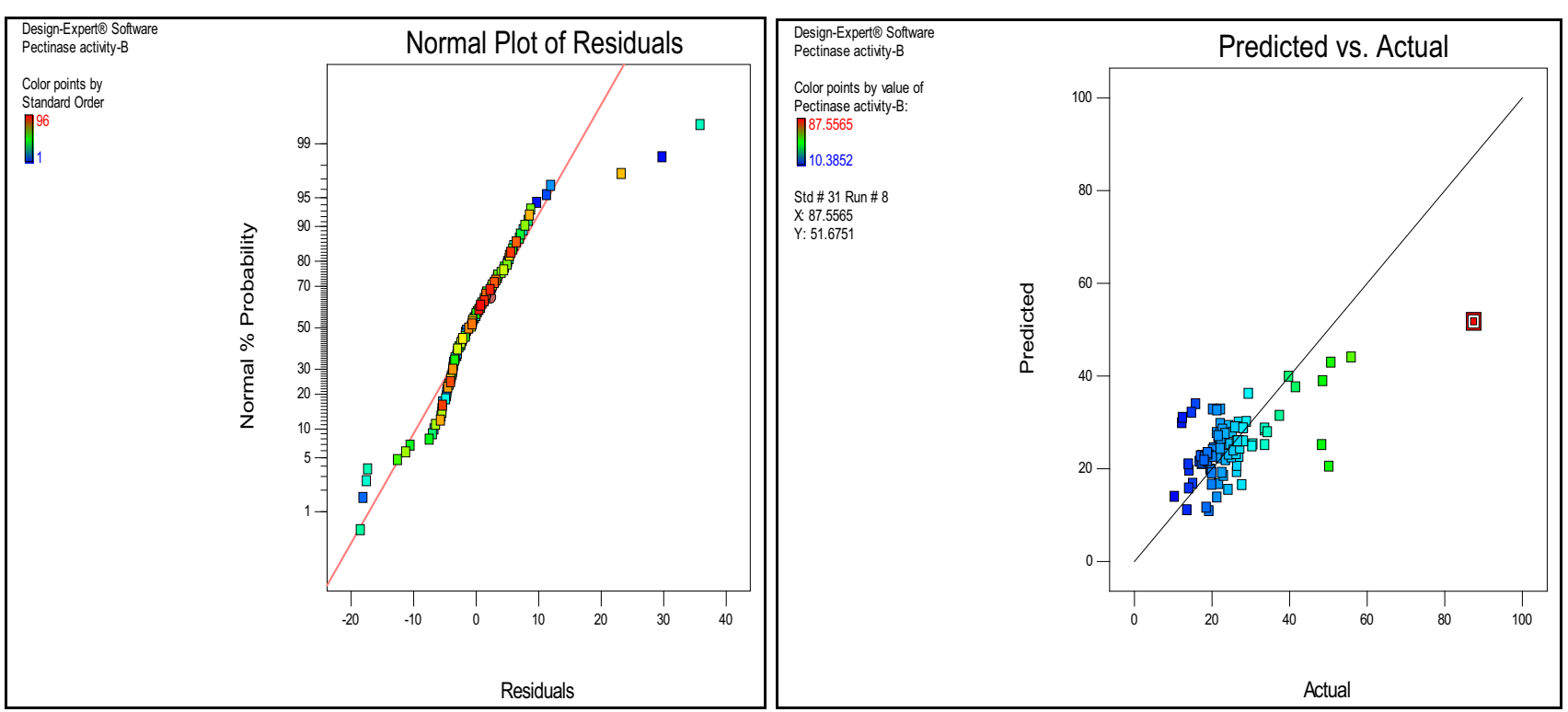

Fig. 2 Plots of normal probability $\%$ and correlation between actual and predicted values
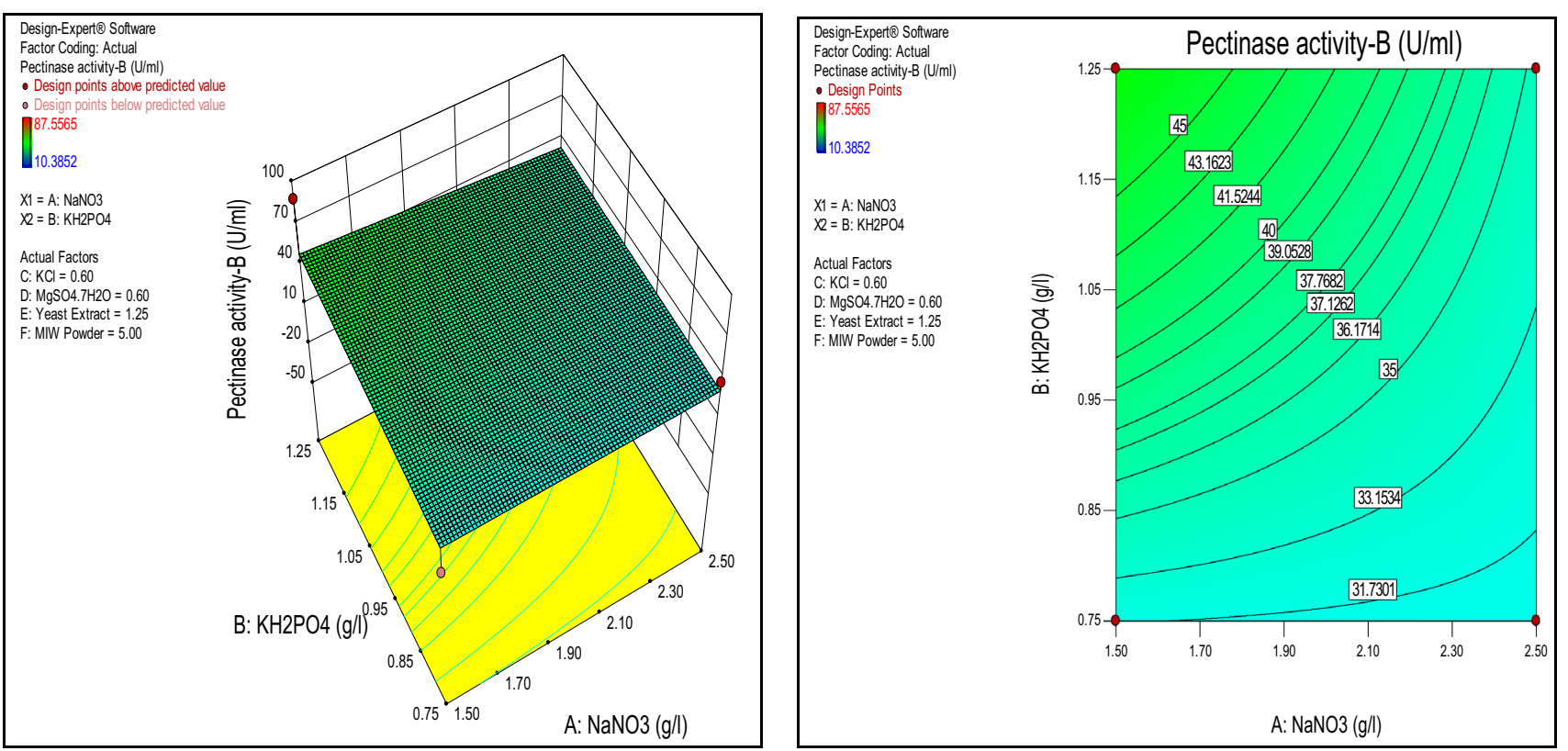

Fig. 3 Response surface plots of effect of $\mathrm{NaNO}_{3}$ and $\mathrm{KH}_{2} \mathrm{PO}_{4}$ on pectinase production

\section{Species identification of PSTB-1 strain}

The 16S r-RNA sequence of isolated bacterial strain PSTB1 has shown more homology with reported strain Enterobacter cloacae sub sp. Cloacae (Fig. 1). The identification of this strain was confirmed by NCBI sequence submission. Similarly, pectinolytic bacterial strains such as Bacillus firmus-I-4071, B. firmus-I-10104 and Bacillus laterosporus-I-107 were reported from agro and fruit processing industrial wastes (Geetha et al. 2012; Veeranjaneya Reddy et al. 2011; Kashyap et al. 2000).

\section{Optimization of media composition}

The experimental results associated with the processing set of each independent variable (Table 1). To study the combined effects of these factors/variables, experiments were conducted at different combinations of these parameters using statistically designed experiments (Table 2). Experimental response along with predicted response was calculated from the regression equation for each run. A second order polynomial equation was derived to represent the pectinase production as a function of independent variables tested (Eq. 2). 


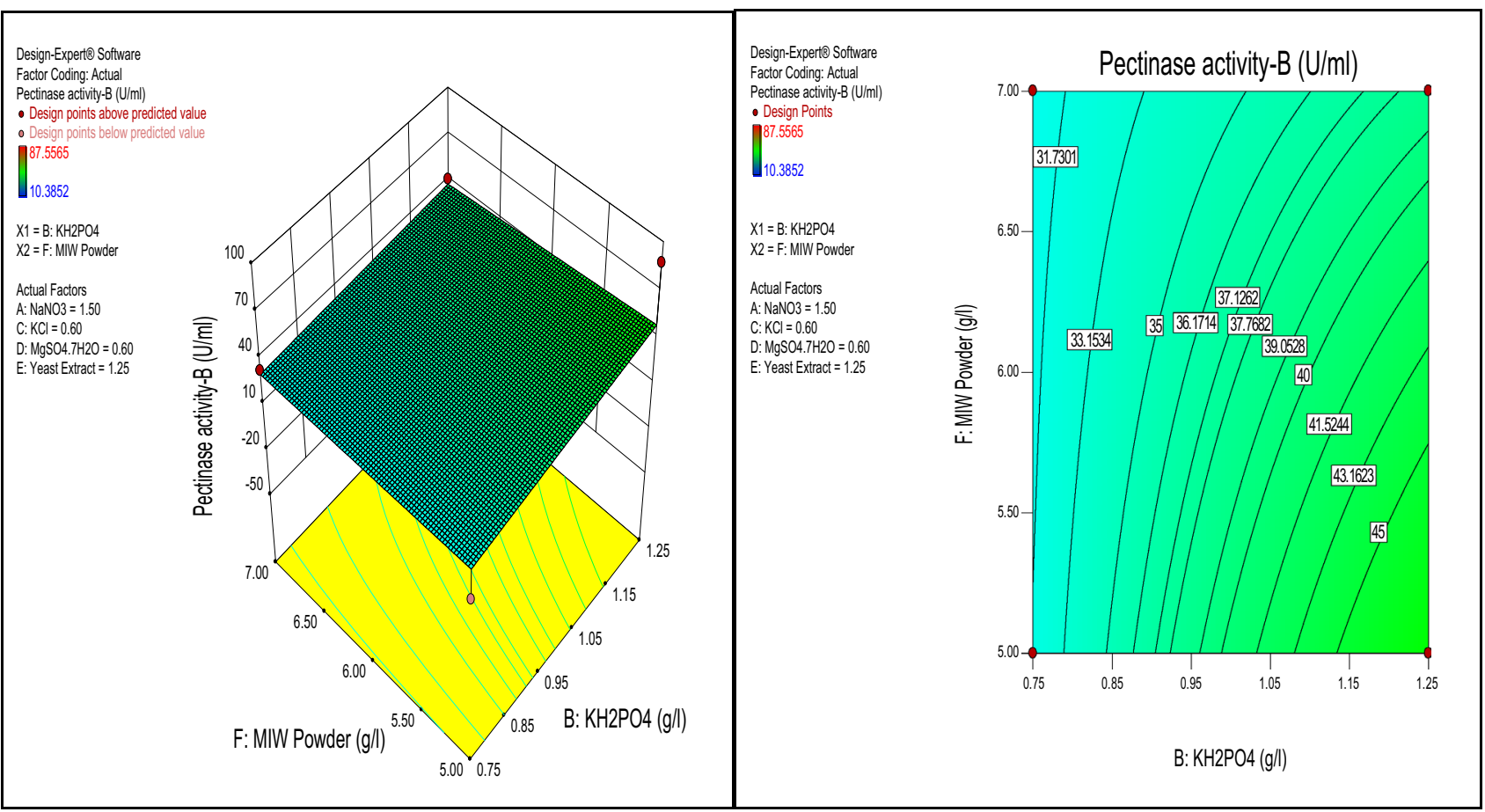

Fig. 4 Response surface plots of effect of $\mathrm{KH}_{2} \mathrm{PO}_{4}$ and MIW powder on pectinase production

\section{Experimental design}

\section{Statistical analysis}

The ANOVA result of quadratic regression model for pectinase yield is described in Table 3 .

Equation:

$$
\begin{aligned}
\text { Pectinase }(\mathrm{U} / \mathrm{ml})= & +28.25-1.62 \times A+2.67 \times B+1.78 \\
& \times C+1.26 \times D+1.02 \times E \\
& -0.71 \times F-3.42 \times A \times B \\
& -1.52 \times A \times C-1.14 \times A \times D-0.87 \\
& \times A \times E+2.13 \times A \times F \\
& +0.93 \times B \times C+0.080 \times B \times D \\
& -0.45 \times B \times E-2.51 \times B \times F \\
& +3.44 \times C \times D+3.43 \times C \times E \\
& -0.71 \times C \times F+1.78 \times D \times E \\
& +0.87 \times D \times F+1.48 \times E \times F \\
& -2.52 \times A^{2}-1.44 \times B^{2}+0.081 \\
& \times C_{2}+1.20 \times D_{2}-0.68 \times E_{2}-0.40 \times F_{2}
\end{aligned}
$$

The statistical significance of Eq. (2) was verified by the ' $F$-test and the 'analysis of variance' for the quadratic model of the response surface (Table 3). The Model F-Valueof 1.74 implies that the model is significant. There is only a $4.66 \%$ chance that a "Model F-Value" this large could occur due to noise. Values of "Prob $>$ F" less than 0.0500 indicate model terms are significant. ANOVA $(F$ test) for the model explained the response of the dependent variable ' $Y$ '. In this case $\mathrm{B}, \mathrm{AB}, \mathrm{BF}, \mathrm{CD}$ and $\mathrm{CE}$ are significant model terms. If there are many insignificant model terms (not counting those required to support hierarchy), model reduction may improve model. Values greater than 0.1000 indicate the model terms are not significant. The $R^{2}$ which can be defined as the ratio of the explained variation to the total variation was a measure of the degree of fit. The closer the $R^{2}$ value to unity, the better the empirical model fits the actual data. The value of determination of coefficient $R^{2}$ is 0.7523 , which indicated that the model could explain $75.23 \%$ of variability and is unable to explain only $24.77 \%$ of the total variation. The closer the value of $R^{2}$ to 1 indicates the better correlation between the observed and predicted values suggesting a good fit for submerged fermentation.

The adjusted $R^{2}$ was a corrected value for $R^{2}$ after elimination of the unnecessary model terms. If many nonsignificant terms have been included in the model, the adjusted $R^{2}$ would be remarkably smaller than the $R^{2}$. The adjusted $R^{2}$ was 0.3663 , which is more suitable for comparing models with different numbers of independent variables. The coefficient of variation (CV) is a measure of residual variation of the data relative to the size of the mean; the small values of $\mathrm{CV}$ give better reproducibility. A 

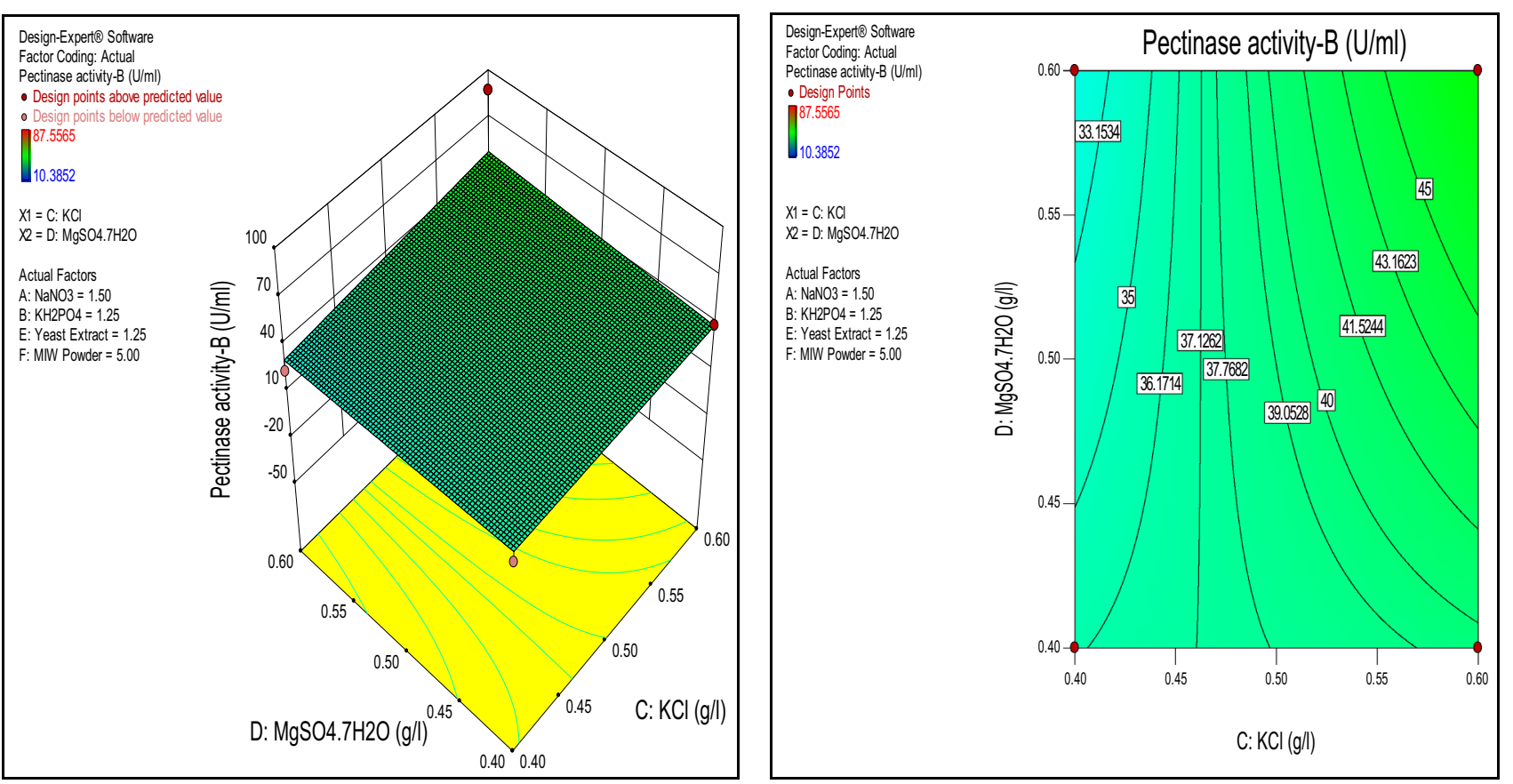

Fig. 5 Response surface plots of effect of $\mathrm{KCl}$ and MIW powder on pectinase production
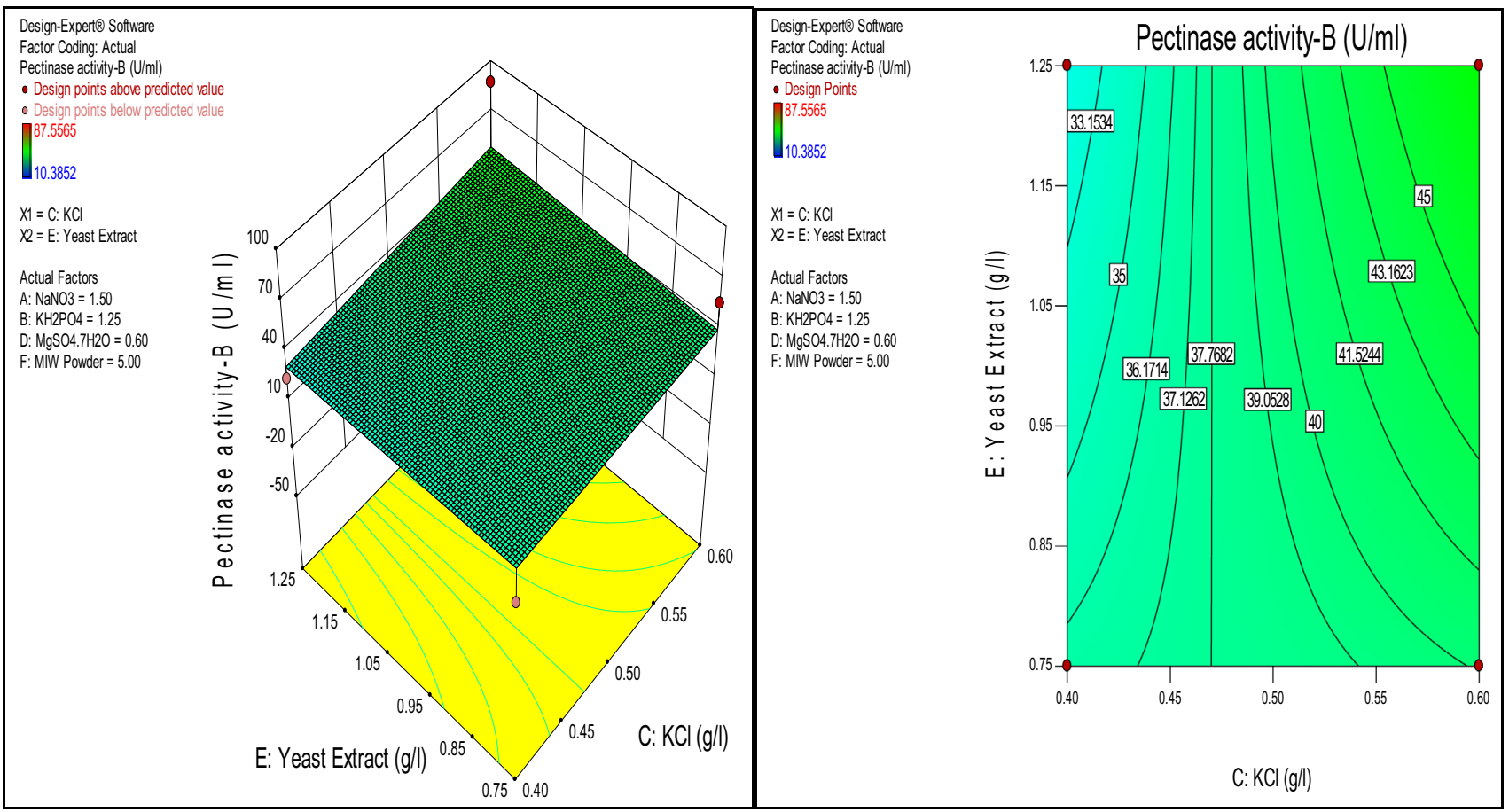

Fig. 6 Response surface plots of effect of $\mathrm{KCl}$ and Yeast extract on pectinase production

lower value for the CV $36.30 \%$ clearly indicates high degree of precision and higher reliability of the experimental values. The significance of individual variables can be evaluated from their $p$ values, the more significant terms having a lower $p$-value. The $p$-values are used to check the significance of each coefficient which also indicates the 
interaction strength between each independent variable. The $p$-values of each of the variables also indicate their quadratic and interaction terms. Besides the relationship between the actual experimental and predicted values, the plotted points cluster around the diagonal line, indicating good fitness of the model and they are in reasonable agreement (Fig. 2). An effect of concentration of $\mathrm{KH}_{2} \mathrm{PO}_{4}$ has shown significance on the pectinase production than $\mathrm{NaNO}_{3}$ and MIW powder was analyzed by the response surface plots (Figs. 3, 4).

Similarly, $\mathrm{KCl}$ has shown significance on the pectinase production than yeast extract and $\mathrm{MgSO}_{4} \cdot 7 \mathrm{H}_{2} \mathrm{O}$, respectively (Figs. 5, 6). All the response surfaces could be analyzed for determining the optimized value of the factors. Enzyme production is a growing field of biotechnology, the majority of the industrial enzymes are of microbial origin. Though there is a conventional method for the optimization of media composition RSM is the best statistical method to optimise all media components at a time. Through this method we can find out the suitable medium with optimal cultural conditions for high production of microbial pectinase by submerged fermentation. In the present study, the Enterobacter sp. PSTB-1 showed pectinase activity ranging from $10.3852 \mathrm{U} / \mathrm{ml}$ (low) to $87.5565 \mathrm{U} / \mathrm{ml}$ (high) under RSM designed conditions. The highest activity $87.5565 \mathrm{U} / \mathrm{ml}$ of Enterobacter sp. PSTB-1 is higher than the pectinase activity $53 \mathrm{U} / \mathrm{ml}$ of Bacillus sp. DT7 and $10.65 \mathrm{U} / \mathrm{ml}$ of Bacillus licheniformis (Shahera et al. 2002; Hou et al. 2011).

\section{Conclusion}

Model summary statistics showed that the predicted model was in close agreement with the experimental data. From the ANOVA results, the second-order polynomial regression model developed has a high correlation $R^{2}$ value. The best conditions were found to be, $\mathrm{NaNO}_{3} 2.0 \mathrm{~g} / \mathrm{l}, \mathrm{KCl} 0.50 \mathrm{~g} / \mathrm{l}$, $\mathrm{KH}_{2} \mathrm{PO}_{4} 1.0 \mathrm{~g} / \mathrm{l}, \mathrm{MgSO}_{4} \cdot 7 \mathrm{H}_{2} \mathrm{O} 0.50 \mathrm{~g} / \mathrm{l}$, Yeast extract $1.0 \mathrm{~g} /$ 1, Mango industrial waste powder $5.0 \mathrm{~g} / \mathrm{l}$. Under these optimized conditions, the experimental value $87.557 \mathrm{U} / \mathrm{ml}$ of enzyme production closely agreed with the predicted value $53.658 / \mathrm{ml}$. This is the first report regarding pectinase production from Enterobacter sp. PSTB-1 by using mango fruit processing industrial waste as a carbon source. The results resembled that the followed design model of response surface methodology (RSM) is the best fit for conducting the experiments to know the required concentrations of media components for the high production of pectinase. It is the cheapest fermentation process for high production of industrially important and microbial derived pectinase.
Acknowledgments Authors are very much thankful to PHCDBBSDr Baba Saheb Ambeddkar Marathwada University, Aurangabad for providing lab facilities to complete the $16 \mathrm{~s}$ rRNA sequencing work successfully.

\section{Compliance with ethical standards}

Conflict of interest The authors declare that they have no conflict of interest.

Open Access This article is distributed under the terms of the Creative Commons Attribution 4.0 International License (http:// creativecommons.org/licenses/by/4.0/), which permits unrestricted use, distribution, and reproduction in any medium, provided you give appropriate credit to the original author(s) and the source, provide a link to the Creative Commons license, and indicate if changes were made.

\section{References}

Alexander P, Parag V, Shariff O, Moissl-Eichinger C, Andersen G, Venkateswaran K (2010) Microbial diversity of anaerobes from spacecraft assembly clean rooms. Appl Environ Microbiol 76:1-26. doi:10.1128/AEM.02167-09

Aneja KR (2003) Experiments in microbiology plant pathology and biotechnology, 4th edn. New Age International, New Delhi, p 320

Attyia SH, Ashour SM (2002) Biodegradation of agro-industrial orange waste under solid stat fermentation and natural environmental conditions. Egypt J Biol 4:23-30

Beatriz B, Fabrice V (2012) Enzymatic liquefaction of cell-walls from kent and tommy atkins mango fruits. Int J Food Sci Nutr Eng 2(5):76-84

Design-expert 9.0.1 (2013) Software-Response Surface Methodology trail version

Geetha M, Saranraj P, Mahalakshmi S, Reetha D (2012) Screening of pectinase producing bacteria and fungi for its pectinolytic activity using fruit wastes. Int J Biochem Biotech Sci 1:30-42

Guzman O, Lemus C, Bugarin J, Bonilla J, Ly J (2013) Composition and chemical characteristics of mangoes (Mangifera indica $\mathrm{L}$.) for animal feeding in Nayarit, Mexico. Cuban J Agric Sci 47(3):273-277

Hou Y, Liu S, Xiong H, Li C (2011) Optimization of polygalacturonase production condition for Bacillus licheniformis 3x05 using response surface methodology. Int Conf Agric Biosyst Eng Adv Biomed Eng 1(2):978-983

Indian Horticulture Database (2011) Chapter-IV, World Scenario. India Data

Kashyap DR, Chandra S, Kaul A, Tewari R (2000) Production, purification and characterization of pectinase from a Bacillus sp. DT7. World J Microbiol Biotechnol 16:277-282

Miller Gail Lorenz (1959) Use of dinitrosalicylic acid reagent for determination of reducing sugar. Ann Chem 31(3):426-428

Mukesh kumar DJ, Saranya GM, Suresh K, Andal Priyadharshini D, Rajakumar R, Kalaichelvan PT (2012) Production and optimization of pectinase from Bacillus sp. MFW7 using Cassava waste. Asian J Plant Sci Res 2:369-375

Naga Venkata, Raju E, Divakar G (2013) Screening and isolation of pectinase producing bacteria from various regions in Bangalore. Int J Res Pharm Biomed Sci 4(1):151-154

Namasivayam E, Ravindar JD, Mariappan K, Akil J, Kumar M, Jayaraj RL (2011) Production of extracellular pectinase by bacillus cereus isolated from market solid waste. J Bioanal Biomed 3(3):70-75 
Purnachandra Reddy M, Saritha KV (2013) Potential Applications of 'King of Fruits' (Mango). Indo-Am J Pharm Res 3(9):7155-7159

Reda Bayoumi A, Hesham M, Yassin Md, Swelim A, Ebtsam Z, Abdel-All EZ (2008) Production of bacterial pectinase (s) from agro-industrial wastes under solid state fermentation conditions. J Appl Sci Res 4(12):1708-1721

Srivastava S (2003) Bergey's Manual of systematic bacteriologyUnderstanding bacteria. Bergey's Manuals, Springer, p 40
Veeranjaneya Reddy L, Vijaya Sarathi Reddy O, Wee YJ (2011) Production of ethanol from mango (Mangifera indica L.) peel by Saccharomyces cerevisiae CFTRI101. Afr J Biotechnol 10(20):4183-4189

Yashoda HM, Prabha TN, Tharanathan RN (2005) Mango ripeningchemical and structural characterization of pectic and hemi cellulosic polysaccharides. Carbohydr Res 340(7):1335-1342 